\title{
A Definition of Digital Markets by the Slovak Antimonopoly Office - Has the Boat to Digitalisation Already Sailed?
}

\author{
by
}

\author{
Hana Kováčiková*
}

\section{CONTENTS}

I. Introduction

II. European approach to the zero-price market

III. Slovak approach to the digital market

IV. Conclusion

\section{Abstract}

Digitalisation has brought new legal challenges even to competition law. The traditional SSNIP test used by competition authorities does not work with online markets, where services or products are made available to consumers free of charge. This paper analyses some aspects of zero-price markets and their assessment from the point of view of European competition authority and from the point of view of the Slovak Antimonopoly Office.

\section{Resumé}

La numérisation a apporté de nouveaux défis juridiques, même en matière de droit de la concurrence. Le test SSNIP traditionnel utilisé par les autorités

* Assistant professor at Faculty of Law, Comenius University in Bratislava, hana.kovacikova@ flaw.uniba.sk. ORCID: 0000-0002-4158-0924. The paper was prepared within the project VEGA No 2/0167/19 (2019-2022) 'The Real Convergence in the European Union: Empirical Evidence and Implications' and Jean Monnet project No. 600587-EPP-1-2018-1-SK-EPPJMO-MODULE: 'Clinical Education in Selected Areas of European Union's Internal Market'.

Article received: 8 April 2020, accepted: 18 May 2020. 
de la concurrence ne convient pas aux marchés en ligne, où les services ou les produits sont mis gratuitement à la disposition des consommateurs. Ce document analyse certains aspects des marchés à prix zéro et leur évaluation du point de vue de l'autorité européenne de la concurrence et du point de vue de l'autorité slovaque de la concurrence.

Key words: competition law; digital competition; market definition; quality assessment; relevant market.

JEL: K20, K21

\section{Introduction}

Digitalisation has spread all over the world. It has affected almost all areas of life and law. Rapid digitalisation raises the question of whether existing regulatory approaches and tools remain appropriate, or whether new sectors and activities would require regulators to rethink competition policy and explore new approaches (OECD, 2018, p. 4). The European Commission, OECD and even national competition authorities have identified various legal challenges. For example, the German Monopolkommission identified in its Special Report No 68 (2015) challenges relating to data collection, online advertising, search engines, social networks or e-commerce. On the other side, the European Commission has been paying attention to defining the new 'digital era' goals and methodologies, definitions of digital markets, platforms, usage of data in competition and need for adaptation of analytical tools, economic theories of harm and legal doctrines (European Commission, 2019).

In the last twenty years, the internet has developed to an open platform of innovations with low barriers of access for content providers or end users. This development fastened after smartphones became a common part of our lives. ${ }^{1}$ As a result, new types of markets were established. In some of them end users even do not need to pay to get online content. The zero-pricing business model is the new phenomena of digital market. The OECD explained the motivation of firms to provide the product without receiving money in exchange referring

1 To be added, pursuant to the findings provided by the European Commission in the merger decision of 7 October 2011 No COMP/M.6281 - Microsoft/Skype (para. 36), in 2011 'only approximately one third of EEA customers have the possibility to substitute a PC by a smartphone in order to communicate over the internet'. 
to four reasons: data acquisition; ${ }^{2}$ advertising $;^{3}$ development of a consumer base $^{4}$ and altruism ${ }^{5}$ (OECD, 2018a, p. 4). Mandrescu adds in this regard that the use of zero-pricing has often been adopted by companies in the context of tying practices, complementary products, two- or multi sided markets and 'freemium' products or services (Mandrescu, 2018, p. 246).

And here comes one of the problems. When defining a relevant market, a traditional SSNIP test would not be of great use, as the competition authority cannot define small but significant non-transitory increase in price (Patakyová and Mazúr, 2018, p. 2303). The use of zero-pricing strategies by online platforms will inevitably eliminate any evidentiary value resulting from the application of the SSNIP test, since such strategy removes the core aspect of the test itself, namely the positive price charged for the product or service offered by the concerned undertaking (Mandrescu, 2018, p. 249). Zero-price business models and the resulting question - how to assess substitution when there is no variation in price (?), is therefore the subject of the research in this article. Surely, digitisation of competition has brought a far wider range of questions. However, as far as the extent of the paper is limited, the author left other topics for further research and academic discussions.

This paper provides an analysis of the European approach to relevant markets with zero-price products and the approach of the Slovak Antimonopoly Office in its decisional practise.

2 The collection of user data has become a key part of digital business models for improving service quality, developing new products, and monetisation through the sale of data to data brokers or other firms.

3 The provision of free goods to attract consumers' attention, which can then be directed towards advertisements, is an established business model in media sectors. However, in digital markets, these advertisements can be tailored to individual consumers, enhancing their effectiveness.

4 A price of zero may also be a part of a firm's strategy to eventually earn revenues from a consumer, for example through limited time free trials, offering a paid option with greater functionality, selling complementary products (including non-durable complements that may be shielded from competition by compatibility limitations or a low tendency among consumers to shop around), or selling other products by making use of the firm's established relationship with zero-price good customers. Zero-price offers may also be a strategy in order to rapidly increase market share when a competitor offers a similar product. Another possibility is that firms offer free goods to accumulate a large user base that will increase the firm's attractiveness as a merger target for other firms.

5 Some technologies, referred to as 'open source', are available at a price of zero and are not conditioned on access to consumer data or advertising revenues. These technologies may be offered without a profit motivation, reflecting broader philosophical views about technology accessibility and innovation. 


\section{European approach to digital market}

From paragraph $15^{6}$ of the Commission's 1997 Notice on the definition of relevant market, one can assume that the Commission positions the SSNIP test as the number one tool to define markets and explicitly says that market definition focuses on prices. However, as Di Porto and Podszun have pointed out, if prices do not play a role or play a minor role for customers, they are stripped of their rationing function and do not explain why markets work the way they do (Di Porto and Podszun 2018, p. 77). Therefore, it was inevitable for competition authorities, to find a suitable alternative.

The Microsoft/Skype ${ }^{7}$ merger case (2011) belongs to early decisions dealing with zero-price products. This merger concerned communication services: Windows Live Messenger, Lync and Skype, which enables instant messaging, voice and video communication. These types of services were mostly offered for free. As a consequence, the Commission identified high price sensitivity in consumer communication services markets. It found out that if a provider starts charging for a service, which was used for a long time free of charge, and alternative free services exist, it can be expected that consumers would immediately switch to competing communication services. Success of providers at these markets therefore depended very much on whether they were free of charge. As in this case market shares provided only a limited indication of competitive strength in consumer communication services markets, the Commission considered that market shares in volume constitute better indicators than market shares in value. Regarding to the alternation to the price, the Commission stated (in para. 81): 'Since consumer communications services are mainly provided for free, consumers pay more attention to other features. Quality is therefore a significant parameter of competition'.

The fact that quality is an important competition parameter was confirmed two years later, when the OECD initiated the 2013 Roundtable on the role and measurement of quality in competition analysis. EU submitted its suggestions ${ }^{8}$

6 The assessment of demand substitution entails a determination of the range of products which are viewed as substitutes by the consumer. One way of making this determination can be viewed as a speculative experiment, postulating a hypothetical small, lasting change in relative prices and evaluating the likely reactions of customers to that increase. The exercise of market definition focuses on prices for operational and practical purposes, and more precisely on demand substitution arising from small, permanent changes in relative prices. This concept can provide clear indications as to the evidence that is relevant in defining markets.

7 Decision of the European Commission of 7 October 2011 No COMP/M.6281 - Microsoft/ Skype.

8 For more information see the European Union's note to this Roundtable, which is available at: https://ec.europa.eu/competition/international/multilateral/2013_june_roundtable_ quality_en.pdf (18.06.2020). 
alongside Australia, Canada, Chile, Indonesia, Japan, Mexico, Portugal, UK, Ukraine, USA, BIAC and OECD itself. The EU, in its note submitted for discussion, stressed that quality degradation has been assessed as a factor of anti-competitive harm, and the extent of possible quality improvements of a merger or agreement have been analysed in the context of efficiencies. Furthermore, as well as the assessment of anti-competitive effects and positive efficiency benefits, which is often focused on price, effects on quality could be of similar relevance. To this regard, Pisarkiewicz and $\mathrm{West}^{9}$ reminded that if competition authorities wish to place a greater focus on quality, they must be prepared to do market-specific empirical work as theories about competition and quality alone will not provide sufficient insights about quality effects in most markets. However, the roundtable did not bring a clear answer to the question what the best alternation to the SSNIP test is. On the other side, a significant benefit could be seen in the attempt for an exhaustive definition of the term 'quality': 'Quality is a multidimensional concept that encompasses, inter alia, the durability, reliability, location, design and aesthetic appeal, performance and safety of a product' (OECD, 2013b, p. 6). Finally, participants, regarding to the question whether markets can and should be defined by means of a quantitative assessment of quality and its competitive impacts, summarised that this could involve the use of a SSNDQ test to assess the impact of a 'small but significant non-transitory decrease in quality'.

Although different opinions exist amongst authors ${ }^{10}$ whether the SSNDQ test is the best alternation to the SSNIP test or not, agreement was achieved that the SSNIP test is not a suitable method for assessing the zero-price markets. Also, the EU competition authority acknowledged the substitutability of the SSNIP test by other methods in its decisional practice. For example, in the 2014 case Licensing of IPR for football collectibles ${ }^{11}$ the Commission noted that the SSNIP test is not the only tool for the purposes of defining the relevant market as other tool, such a market studies and the assessment of consumers and other competitors' view point, may be useful in this respect.

9 They acted on behalf the OECD's Secretariat. Secretariat's note prepared by Pisarkiewicz and West is available at: https://www.academia.edu/6407640/The_Role_of_Quality_in_ Competition_Analysis?auto=download (18.06.2020).

${ }^{10}$ For example, Caffara and Latham $(2017$, p. 6) advocate for the SSNDQ test as well as Mandrescu. On the other side of barricade, we can find the rather sceptical Franck and Peitz (2019, p.65) or Di Porto and Podszun. Sousa Ferro (2015, p. 2) notes that the greatest obstacle to the development of a unified theoretical position on the relationship between gratuity and competition law, in what concerns its applicability and market definition, has been the lack of differentiation between fully gratuitous situations and situations of gratuitous supply with an impact on paid products, as well as the distinction between different degrees of impact.

11 Decision of the European Commission of 15 June 2014, Case AT.39899 - Licensing of IPRs for football collectibles, para. 41. 
Furthermore, the Commission stressed, that it does not follow a rigid hierarchy of different sources of information or types of evidence. ${ }^{12}$

The inapplicability of the SSNIP test for zero-price markets and the suitability of other methods was further confirmed by the Commission in its later decisional practice. For example, in the 2017 Google Search (Shopping), ${ }^{13}$ the Commission stated that (para. 153) 'it must take an overall assessment and take account of a range of tools for the purpose of that assessment; and that SSNIP test (para. 243) is not the only method available to the Commission when defining the relevant market; (para. 245) would not have been appropriate in the present case because Google provides its search service for free to users'. Such approach of the Commission was repeated also in the 2018 case Google Android. ${ }^{14}$

To sum up this part, one can assume that the EU competition authority has been trying hard to keep up with the digital revolution by abandoning unsuitable methods and applying various appropriate ones. Such approach reflects dynamics in development and national competition authorities shall follow it.

12 This Commission's decision was later confirmed by the GC judgment of 11 January 2017, Case T-699/14 Topps Europe Ltd v European Commission, ECLI:EU:T:2017:2, where the Court in paras. 80 and 82 stated: 'It is to be noted that the Commission has a certain discretion concerning the definition of the relevant market, in so far as that definition involves complex economic assessments. (...) In the present case, as regards, first of all, the applicant's argument that the Commission ought to have carried out an SSNIP test, it must be found that although that type of economic test is indeed a recognised method for defining the market at issue, it is not the only method available to the Commission. It may also take into account other tools for the purposes of defining the relevant market, such as market studies or an assessment of consumers' and other competitors' points of view. The SSNIP test may also prove unsuitable in certain cases, for example in the presence of the 'cellophane fallacy', that is, the situation where the undertaking concerned already holds a virtual monopoly and the market prices are already at a supra-competitive level, or where there are free goods or goods the cost of which is not borne by those determining the demand. It is also apparent from point 25 of the Commission notice on the definition of relevant market for the purposes of Community competition law (OJ 1997 C 372, p. 5) that the definition of the relevant market does not require the Commission to follow a rigid hierarchy of different sources of information or types of evidence. The Commission did not, therefore, commit a manifest error of assessment in basing its conclusions on the relevant market on its assessment of the evidence gathered without having recourse to an SSNIP test'.

13 Decision of the European Commission of 27 June 2017, Case AT.39740 Google Search (Shopping).

14 Decision of the European Commission of 18 June 2018, Case AT.40099 Google Android, paras. 263-265. 


\section{Slovak approach to the digital market}

Despite the ongoing digitalisation of all areas of the economy, it seems that the Slovak competition environment has remained untouched or just very slightly touched by it. In the last five years, the Antimonopoly Office has dealt at least with three cases relating to digital market area. However, the Antimonopoly Office did not use the chance to define digital relevant market in any of them.

Firstly, in the 2016 merger case Petit Press ${ }^{15}$ (Petit Press is one of major Slovak publishing houses), the Antimonopoly Office identified the existence of various relevant markets for publishing, providing information and advertisement in printed periodical media and, at the same time, digital markets for providing information and advertisement on web-portals. The market for print media was split into several sub-markets based on the content of the newspaper or journal, periodicity, territorial coverage, price, quality of paper, as well as target groups. Similarly, on-line media was also split into several relevant 'submarkets'. A zero-price market with online content was recognised for end users. To this regard, the Antimonopoly Office assessed the numbers of visits on the examined webpages as the relevant criteria and decided that users are able to change the assessed web portals to another at no cost and in no time. This aspect was not included in the analysis itself, and the Antimonopoly Office concluded, that the possible impact of shares in the on-line sphere will be included in a separate analysis of the advertisement market. ${ }^{16}$

The advertisement market was then divided into offline and online markets. The on-line media market was distinguished from the offline market by using the Google/Double Click ${ }^{17}$ criteria whereby (i) on-line media enables stricter aiming to the potential consumer of the goods sold by advertiser, (ii) evaluation of 'success' of advertisement is simply measured by the numbers of views/clicks on it and adding that (iii) in these types of media there exists various pricing of advertisement. The Antimonopoly Office then stated (in para. 280) that it did not find any reason to distinguish between the various forms of on-line advertising regarding to its

15 Decision of the Protimonopolný úrad Slovenskej republiky of 3 June 2016 No 2016/ FJ/3/1/025 - Petit Press.

16 Ibidem, para. 159.

17 Decision of the European Commission of 11 March 2008 No COMP/M.4731 - Google/ DoubleClick, para. 45: '...the market investigation revealed that offline and online advertising are perceived as separate markets by the majority of respondents. Furthermore, online advertising is used for specific purposes. As opposed to offline advertising, online advertising is considered to be capable of reaching a more targeted audience in a more effective way. (...) In addition to this specific targeting, respondents to the market investigation noted that online advertising has a unique reporting system that enables the advertiser to check exactly how many users have viewed the ad or clicked on it, moreover allowing a rapid 'retargeting' of the ad...'. 
content, as the effect of the impact, visibility, price and discount were identified by advertisers as relevant factors. However, regarding to the detailed analyses of the possible impact of shares in the on-line market, the Antimonopoly Office applied the same traditional criteria of market shares of the participants of the concentration and their competitors, and market shares of the individual products on both traditional and digital markets. Market shares were calculated via an approach based on shares of revenues. Finally, the final assessment includes the decision that this merger does not raise serious doubts on competition due to external pressure of 'search' advertisement by Google and Facebook. ${ }^{18}$

Despite the fact that the Antimonopoly Office was aware of new approaches to digital markets and different business and technical models of foreign companies (Google and Facebook), its approach to the assessment of market shares and market power remained traditional. The Antimonopoly Office did not react to the zero-price market in any way.

However, in 2017, the Antimonopoly Office acknowledged e-commerce as its priority and opened a sector inquiry to thoroughly map the affected markets, the level of competition in them, as well as factors with the potential to influence their current situation or their future development (Protimonopolný úrad Slovenskej republiky, 2017, p. 88). The Antimonopoly Office questioned various online retailers selling white goods, brown goods, mobile devices, baby transport, sports/outdoor products and house/garden products. The sector inquiry ended in May 2018. E-commerce remained a priority of the Antimonopoly Office even in 2018 (Protimonopolný úrad Slovenskej republiky, 2018, p. 48). To this regard, it is necessary to note, that up to this date the Antimonopoly Office has not provide any official survey or study regarding this sector inquiry. ${ }^{19}$

However, partial outcomes were presented by the Antimonopoly Office at a conference Current Trends in Slovak and European Competition Law, held in May 2019 in Bratislava. ${ }^{20}$ The presented preliminary findings showed that the growth of Slovak online markets is slower than in the neighbouring countries, but markets have been still developing. Slovak online retailers do not sell via the markets and they have to be active on comparison websites to stay competitive. ${ }^{21}$

18 Petit press, para. 299.

19 However, some data can be collected from other sources. For example, according to the eCommerce bridge, in Slovakia in 2017, more than 11000 e-shops had been established with revenues exceeding 930 millions eur. See https://www.ecommercebridge.sk/ako-vyzeraslovensky-e-commerce-trh-rychly-prehlad/ (18.06.2020).

20 For more information see the presentation by Fillova from the Slovak Antimonopoly Office. Retrieved from: https://www.antimon.gov.sk/data/files/1081_ivona-filova_e-commercesector-inquiry-preliminary-findings.pdf

21 Presented relevant factors in this regard: (i) price is the most relevant for consumers - they can easily compare the offer; (ii) customer reviews matter, but are just one-sided as 
During the sector inquiry, the Antimonopoly Office got another chance to approach digital markets - in the 2018 merger case Nový čas ${ }^{22}$ (Nový čas is the best selling Slovak tabloid daily paper). It established that Nový čas provides, besides printed publishing services, also online content on various web portals (www.cas. sk and www.tivi.sk) as well as advertisement services. However, in its decision, it just referred do the definition of relevant markets provided in the 2016 Petit press case for printed papers. ${ }^{23}$ Regarding the online markets, the Antimonopoly Office only stated that, after considering the announced share of the Nový čas, 'it did not identify any serious doubts relating to competition in this area'.

Finally, in the 2019 Chicco case ${ }^{24}$ the Antimonopoly Office decided on infringement of Article 101(1)(a) TFE U and Article 4(4)(a) of the Slovak Act on Protection of Competition ${ }^{25}$ by the undertaking ags 92, s.r.o. (hereinafter: only ags 9). Ags 92 is one of the most important sellers of Chicco brand kids' product in Slovakia and Czechia. During the years 2013-2018, it applied resale price maintenance to its online distributors. The relevant market covered internet e-shops providing the sale of baby goods to final consumers. One could expect, referring to the declared prioritization of e-commerce, that the Antimonopoly Office would provide an exhausting definition of the relevant market, assessing also the digital aspects of it. However, the Antimonopoly Office stated that in cases of cartel agreements, whose object was to restrict competition, it is not obliged to define the relevant market in a strict manner. ${ }^{26}$

The approach of the Slovak Antimonopoly Office to digital market therefore remains unknown.

retailers do not have the opportunity to respond directly to the negative reviews; (iii) 'per click' and 'positioning' costs have increased; (iv) the offers of dishonest retailers occur and affect fair competition.

22 Decision of the Protimonopolný úrad Slovenskej republiky of 6 February 2018 No 2018/ $\mathrm{KOH} / \mathrm{SKO} / 3 / 4$ - Nový čas.

${ }^{23}$ By explicit refference to paras. 79-80 of the Petit press decision, which identified the relevant markets in the area of printed daily paper publishing (nationwide daily papers and regional daily papers).

${ }^{24}$ Decision of the Protimonopolný úrad Slovenskej republiky of 15 July 2019 No. 2019/ DOV/POK/2/20 - Chicco.

25 Act No 136/2011 Coll. on Protection of Competition and on Amendments and Supplements to the Act of the Slovak National Council No. 347/1990 Coll. on Organisation of Ministries and Other Central Bodies of State Administration of the Slovak Republic as amended.

26 See para. 40 in the Chicco decision: 'The Office examined the behaviour of ags 92 s.r.o. in relation to the entire offer of Chicco brand supplied by the undertaking ags 92 . Since there is a target vertical agreement, where it is not necessary to define the goods relevant market precisely, the Office did not examine in detail the characteristics of each Chicco product category compared to other producers of the potential interchangeability of products within each category'. 


\section{Conclusions}

The digital revolution means that the SSNIP test is no longer a usable tool for market definition in cases where products and services are provided for free; it does not meet the challenges brought about by digital markets. However, the SSNIP test is not the only tool - there is a range of evidence making it possible to assess the extent to which substitution would take place. Therefore, if the SSNIP test is not usable, the competition authority should use another appropriate tool.

The European example proves that even with old-fashioned legislation, ${ }^{27}$ but wide-open interpretation of it, new challenges, brought by digital evolution, could be met. The Slovak Administrative Code binds the Slovak Antimonopoly Office to use the most appropriate tools leading to a correct decision. Furthermore, a 'decision in any case must be based on reliable established factual basis'. ${ }^{28}$ In this regard, the Slovak Antimonopoly Office is obliged to find out the exact and absolutely real state of affairs and for this purpose, obtain necessary evidence. ${ }^{29}$ The Slovak Antimonopoly Office is, therefore, free to use any appropriate tool, which enables it to define a relevant market even with zero-priced products or services. With such general approach, Slovakia does not need to adapt its legislation to new developments, as it reflects the dynamics of development just by a proper interpretation by the competition authorities.

However, courage to launch an expert discussion and apply new tests to explore and assess the digital market is still lacking. The solution might be found in the creation of specialised data, technology and analytics team within the Antimonopoly Office, which will be able to suggest and asses other aspects of the relevant online market, rather than the price.

Whether the 'other' type of assessment of the relevant market should be based on quality and the SSNDQ test, is the subject of academic discussion. It

27 Para. 25 of the Notice on the definition of relevant market: 'There is a range of evidence permitting an assessment of the extent to which substitution would take place. In individual cases, certain types of evidence will be determinant, depending very much on the characteristics and specificity of the industry and products or services that are being examined. The same type of evidence may be of no importance in other cases. In most cases, a decision will have to be based on the consideration of a number of criteria and different items of evidence. The Commission follows an open approach to empirical evidence, aimed at making an effective use of all available information which may be relevant in individual cases. The Commission does not follow a rigid hierarchy of different sources of information or types of evidence'.

28 Article 3 of the Act No. 71/1967 Coll. on Administrative Proceedings (Administrative Code).

29 Article 32. 
would be useful if the Slovak Antimonopoly Office takes part it this discussion, too. Clearly, the SSNDQ test is based on complex empirical analysis provided to every case individually, which may have a deterring effect on the competition authority. However, since there are only very few cases in Slovakia dealing with digital markets, the SSNDQ test might present a good solution for relevant market assessment. At least until a new general approach to this agenda will be developed.

From the discussion papers, policy papers, expert papers and case law we can conclude that European competition authorities are on a good road to find appropriate solutions to these legal challenges. The Slovak Antimonopoly Office could be, therefore, recommended to follow their spirit.

\section{Literature}

Caffarra, C. and Latham, O. (2017). Market Definition in the Digital Age. Retrieved from: http://www.konkurrensverket.se/globalassets/english/research/pros-and-cons2017_5cristina-caffarra.pdf (18.06.2020).

Centre on Regulation in Europe (2019). Market Definition and Market Power in the Platform Economy. Retrieved from: https://www.cerre.eu/sites/cerre/files/2019_cerre_market_ definition_market_power_platform_economy.pdf (18.06.2020).

Di Porto, F. and Podszun, R. (2018). Abusive Practices in Competition Law. Edward Elgar Publishing, https://doi.org/10.4337/9781788117340.

European Commission (2019). Competition policy for the digital era. Luxembourg: Publications Office of the European Union, https://doi.org/10.2763/407537. Retrieved from: https://ec.europa.eu/competition/publications/reports/kd0419345enn.pdf (18.06.2020).

Fillova, I. (2019). E-commerce sector inquiry - preliminary findings. Retrieved from: https://www.antimon.gov.sk/data/files/1081_ivona-filova_e-commerce-sector-inquirypreliminary-findings.pdf (18.06.2020).

Mandrescu, D. (2018). The SSNIP Test and Zero-Pricing Strategies: Considerations for Online Platforms. European Competition and Regulatory Law Review, 4, https:// doi.org/ 10.21552/core/2018/4/4. Retrieved from: https://openaccess.leidenuniv.nl/ bitstream/handle/1887/69424/SSNIP_Test_Zero_pricing_DMandrescu.pdf?sequence =1 (18.06.2020).

Monopolkommission (2015). Competition Policy: The challenge of digital markets. Special Report No 68. Special Report by the Monopolies Commission pursuant to section 44(1)(4) of the Act Against Restraints on Competition. Retrieved from: https://www. monopolkommission.de/images/PDF/SG/s68_fulltext_eng.pdf (18.06.2020).

OECD (2013). Roundtable on the role and the measurement of quality in competition analysis. Note by the Secretariat of 4 June 2013 No DAF/COMP(2013)8. Retrieved from: https://www.academia.edu/6407640/The_Role_of_Quality_in_Competition_ Analysis?auto=download (18.06.2020). 
OECD (2013a). Roundtable on the role and the measurement of quality in competition analysis. Note by the European Union of 13 June 2013 No DAF/COMP/WD(2013)32. Retrieved from: https:/ec.europa.eu/competition/international/multilateral/2013_june_ roundtable_quality_en.pdf (18.06.2020).

OECD (2013b). Roundtable on the role and the measurement of quality in competition analysis. Retrieved from: http://www.oecd.org/competition/Quality-in-competitionanalysis-2013.pdf (18.06.2020).

OECD (2018). Maintaining competitive conditions in the era of digitalisation. OECD report to G-20 Finance Ministers and Central Bank Governors. Retrieved from: https://www. oecd.org/g20/Maintaining-competitive-conditions-in-era-of-digitalisation-OECD.pdf (18.06.2020).

OECD (2018a). Quality considerations in digital zero-price markets. Background note by the Secretariat. Retrieved from: https://one.oecd.org/document/DAF/COMP(2018)14/en/ pdf (18.06.2020).

OECD (2018). Rethinking Antitrust Tools for Multi-Sided Platforms. Retrieved from: http://www.oecd.org/daf/competition/Rethinking-antitrust-tools-for-multi-sidedplatforms-2018.pdf (18.06.2020).

Patakyová, M.T. and Mazúr, J. (2018). Facebook - Global issue without (existing) solution?. In: Globalization and its socio-economic consequences: proceedings. Žilina: Žilinská univerzita v Žiline, p. 2298-2306 (online). Retrived from: https://globalization.uniza.sk/ wp-content/uploads/2018/12/proceedings_globalization_2018_part_5.pdf (18.06.2020).

Protimonopolný úrad Slovenskej republiky (2017). Elektronické trhovisko (EKS) podlimitné zákazky. Retrived from: https:/www.antimon.gov.sk/data/att/1879.pdf (18.06.2020).

Protimonopolný úrad Slovenskej republiky (2018). Výročná správa/Annual Report 2018. Retrived from: https://www.antimon.gov.sk/data/att/2044.pdf (18.06.2020).

Protimonopolný úrad Slovenskej republiky (2017). Výročná správa/Annual Report 2017. Retrived from: https://www.antimon.gov.sk/data/att/1982.pdf (18.06.2020).

Sousa Ferro, M. (2015). 'Ceci n'est pas un Marché': Gratuity and Competition Law. Concurrences/Competition Law Journal, 1. Retrieved from: at: https://papers.ssrn.com/ sol3/papers.cfm?abstract_id=2493236 (18.06.2020).

Waehrer, K (2016). Online Services and the Analysis of Competitive Merger Effects in Privacy Protections and Other Quality Dimensions. Retrived from: https://papers.ssrn.com/sol3/ papers.cfm?abstract_id=2701927 (18.06.2020). 